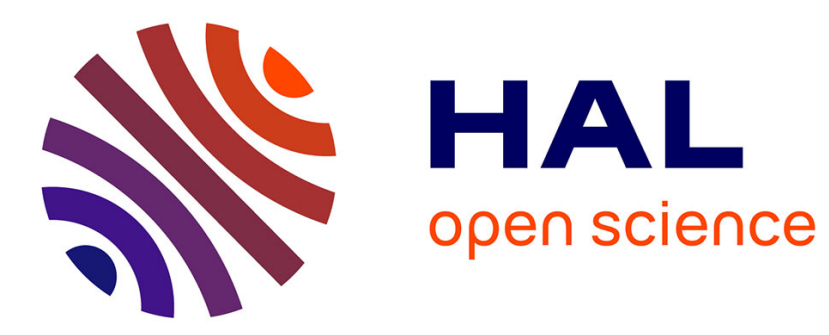

\title{
Understanding expert practices in order to control expert activities: The case of trading
}

Rémi Jardat, Jérôme Méric, Flora Sfez

\section{To cite this version:}

Rémi Jardat, Jérôme Méric, Flora Sfez. Understanding expert practices in order to control expert activities: The case of trading. Canadian Journal of Administrative Sciences - Revue Canadienne des Sciences de l'Administration, 2018, 35 (349- 360), 10.1002/CJAS.1463 . hal-01692242

\section{HAL Id: hal-01692242 \\ https://hal.science/hal-01692242}

Submitted on 24 Jan 2018

HAL is a multi-disciplinary open access archive for the deposit and dissemination of scientific research documents, whether they are published or not. The documents may come from teaching and research institutions in France or abroad, or from public or private research centers.
L'archive ouverte pluridisciplinaire $\mathbf{H A L}$, est destinée au dépôt et à la diffusion de documents scientifiques de niveau recherche, publiés ou non, émanant des établissements d'enseignement et de recherche français ou étrangers, des laboratoires publics ou privés. 
Understanding expert practices in order to control expert activities: The case of trading

Rémi Jardat, Maître de conférences HDR - IRG Université Paris Est EA 2354

remi.jardat@u-pec.fr ,

Jérôme Meric, Professeur des Universités - CEREGE-IAE, Université de Poitiers

jmeric@poitiers.iae-france.fr*

Flora Sfez, Maître de Conférences - CEREGE-Université de Poitiers

flora.sfez@univ-poitiers.fr

*Please address correspondence to : Jérôme Meric, Université de Poitiers, CEREGE-IAE, 20 rue Guillaume VII le Troubadour, POITIERS, 86022, France. Email :

jmeric@poitiers.iae-france.fr 


\section{Abstract}

Experts are important actors of organizational control. Nevertheless, experience suggests that they must be controlled as well. This is particularly the case for traders in financial institutions. We first identify the limits of traditional control patterns when the managing the activities of experts is at stake. Hyperspecialization, which is the ability to act within different logics and multiple time horizons, suggests that multidimensional representations of these activities be adopted and made explicit, which has the potential to prevent such activities from turning problematic. By examining bank risks and conducting additional interviews with actors from bank trading services, we recommend that multiple components of complexity be preserved when dealing with expert-related operational risks, instead of reducing this complexity to a single concept. Such an approach implies to turn back expertise against itself.

Keywords: expert, control, praxis, trading, bank

\section{Résumé}

Les experts sont des acteurs importants du contrôle et de la gestion des risques dans les organisations, pour autant l'expérience montre qu'ils doivent aussi être contrôlés. C'est particulièrement le cas des traders dans les établissements financiers. Dans cet article, nous examinons, par le prisme de la pratique, les limites des schémas du contrôle traditionnel lorsqu'il s'agit de maîtriser l'activité des experts. L'hyper-spécialisation, la capacité à agir en combinant des logiques distinctes dans des horizons-temps multiples invitent à adopter une représentation multidimensionnelle de ces activités pour les expliciter et, potentiellement, en éviter les dérives. En nous fondant sur les travaux d'un projet de recherche portant sur la gestion des risques bancaires, et en les complétant par une série d'entretiens avec des acteurs du trading bancaire, nous proposons de préserver les multiples constituants de la complexité des risques opérationnels 
liés aux activités d'expert, plutôt que de la réduire à un concept unique. Une telle démarche requiert notamment de retourner l'expertise contre elle-même.

Mots-clés : expert, contrôle, praxis, trading, banque 
Experts are active agents of control. However, particularly in management science, it must not be forgotten that they are also players who themselves should be controlled. The current situation is far from the notion of experto credite insofar as experts' judgment is open to debate, such as that between behavioural and cognitive psychologists (Shanteau, 1988). The behavioural camp attests to the lack of validity and reliability of their judgment in psychometric studies (Einhorn, 1974), while probabilistic research in a number of fields points out inconsistencies and measurement errors in the work of experts (such as in medicine, De Smet, Fryback, Thombury, 1978). Cognitive psychology has a more positive opinion of experts, demonstrating their superiority over novices (Siegler, 2013), and emphasizing their skills and qualifications (Chi, Glaser, \& Farr, 1988), such as the case of auditing expertise, where skills are the key legitimizing factor (Bedard, 1989).

While they disagree on experts' greater or lesser room for improvement, behavioural and cognitive psychologists do agree on the question of controlling experts by the sole measure of competence. Competence, according to psychologists, is a sufficient condition to legitimize expertise, an obligation of means rather than results. However, this control mechanism is not exerted by the companies that employ the experts, but rather by their peers - the professional community to which they belong. In essence, competence acts a double mechanism: social control as well as self-control (Abernethy \& Stoelwinder, 1995). Professional associations uphold the competencies of their membership, disseminate knowledge, and may have disciplinary authority over their members. The state also plays a role in regulating experts, and legitimizing their status by granting them the right to practice (Kunitz, 1974); they allow professional associations to remain autonomous, and grant them the right to control their work. The French professional auditors' association (the Ordre des Experts-Comptables - OEC) and financial market association (International Capital Markets Association - ICMA) exert peer control 
through their own regulatory mechanisms. The loyalty of experts to professional associations (that is, peer recognition) is often greater than their allegiance to an employer (Orlikowski, 1991). It is therefore reasonable to ask how a company can exert control that has already been delegated - a question faced by any organization wishing to control the experts in its employ. This question is so much challenging that it is probably why the issue of expert control has been subject to so little study.

The question notably resurfaced after the 2008 financial crisis and following the new recommendations of the Bank for International Settlements (Basel II to Basel III) when a community of banking professionals and researchers became aware of the importance of managing operational risk to ensure the effective regulation of banking activities. Research led by the ANR-C2 R (Control Risk Resiliency) consortium mapped operational risk by identifying a number of checkpoints. However, this mapping activity was static, and unable to take into account the evolving risks inherently caused by expert creativity — an observation that redirected the research, which was divided into two study groups. One group sought to identify control mechanisms for routine activities, while the other group, which included one of the authors of the present article, studied emerging risk dynamics tied to trading activities. The research presented here stems from the work of the second group. Our objective is twofold. First, we will demonstrate the reasons for which control mechanisms are doomed to fail when they are designed to regulate expert-initiated activities. This section focuses on defining the notion of expertise and on demonstrating the challenges of controlling financial experts through examples from financial history and recent accounting standards. Practice is an unavoidable element of understanding expert activities. Bureaucratic attempts to control experts in fields such as trading are all the more inefficient given that this category of experts tend to assert their legitimacy by developing increasingly specialized skills. The second objective of this study is to propose an 
expert control model derived from a case study related to the Control Risk Resiliency project, based on detailed research methods, and with results showing that expert control requires an integrated, dynamic, multidimensional understanding of expert activities. The integration of the case study results raises several issues, which we consider in the discussion section: (i) controlling experts by turning expertise against itself ; and (ii) the need for integrated, dynamic, multidimensional control mechanisms.

\section{Control and Expert Skill Sets: The Need for Multidimensional Reference Frameworks}

Although expertise is a fairly well-defined concept (specific and exclusive knowledge) that has been widely studied (Farrington-Darbi \& Wilson, 2006), the identification of experts within companies is relatively lacking (Buton, 2006). The Latin root of the word, experiti, refers to one who has faced danger (Trépos, 1986). This definition raises the question of what raises an individual to the status of expert. The notion of expertise furthermore has different and complementary implications depending on the field in question.

From a psychological point of view, to be an expert means to possess above-average knowledge (that is, expertise) in a given field (Chi, 2006). This superior knowledge may be relative (measured by individual performance) or absolute (measured by level of knowledge). Professionals in a given field are therefore best positioned to define the qualifications for expertise in their own field because they are able to assess competences (Shanteau, 1992). Knowledge alone is not enough, however, and experts must also behave as such in their public presentation, and adopt the characteristic traits of self-confidence and the ability to adapt to new situations (Shanteau, 1988). Knowledge and skill are the benchmarks controlling the means of accession to the status of expert. 
Sociologically, experts are considered a social construction arising from the dialectical tension between experience and field of representation. An expert is thus acknowledged as a social phenomenon (Evetss, Mieg, \& Felt, 2006) embodied in professionalization, practice, or particular situations. From this point of view, expert control is limited by the dynamics of status construction (Selinger \& Crease, 2006). How is it possible to control that which is the process of being shaped?

In management science, an expert is a professional who excels in his or her field, and whose specific knowledge is based in skills acquired as a result of considerable personal investment (Lelebina \& Sardas, 2011). An expert's knowledge is a strategic asset for his or her company. An expert may be creative (Fablet \& Lacaze, 2014), which is not necessarily true for all professionals, and that creativity may be put to good use by the company, notably to avoid or undermine control mechanisms.

Regardless of the approach and the underlying characteristics that define an expert, experts are predisposed to stand as major players in implementing and applying control mechanisms and, paradoxically, their above-average knowledge allows them to innovatively sidestep regulations, or at the very least rise above them while complying with them. This paradox gives rise to extremely complex situations that conventional representations of control cannot satisfactorily grasp. An integrated, dynamic, and multidimensional approach is preferable.

\section{Expert creativity and the challenge of traditional control and regulation mechanisms}

Researchers with an interest in knowledge professionals (Bouchez, 2006) have generally defined experts in opposition to creative individuals. Experts, such as commercial bankers, solve complex problems using skills, while creative people, such as design professionals, offer innovative solutions. Experts can therefore be said to rely on their knowledge base to practice a profession without innovating. Yet experts are also forced to expand their knowledge base by 
creating products, processes, or standards that only their professional community is able to understand and verify. External, professional regulations prevail over internal, company regulations (Montagna, 1968).

Thévenet (2006, p. 20) noted that experts are autonomous - that is, they operate at "a distance from company regulations, principles, and orders." Autonomy rests the central challenge of expert control, since experts fall outside legitimate company authority. Experts are the reference in their field, and must allow their employer to develop and improve based on their knowledge. Yet more often than not, experts remain solitary, working beyond the governance and control bodies of their employers and environments. Instead, professional organizations, whether formal (for instance, the French Ordre des Experts Comptables) or informal (front-office directors in trading rooms) confer and legitimize expert status. These control mechanisms (Charrier, 2014) are parallel or external to the company, overriding company mechanisms to exert authority over experts.

Abernethy and Stoelwinder (1985) also highlighted the need to recruit professionals to control complex processes. However, the control process itself is at odds with the autonomy of the experts in charge of those control processes. Conflicts arise as soon as professionals who seek to preserve or increase their economy are faced with bureaucratic or administrative systems. Successful control requires the implementation of a system to regulate the economy of experts-a laudable solution in principle, but of which the particularities of implementation are seldom explored.

Experts have a paradoxical relationship with control. On one hand, experts are called upon to regulate their peers' activity, with professional regulations and procedures filling in any gaps. On the other hand, experts may sidestep the standards they and their peers have established, using their creativity to implement solutions adapted to a more complex world (to say nothing of 
the simple attraction of technical complications or personal interests). Experts are potentially uncontrollable controllers. This paradox is a considerable challenge for organizations that rely frequently on experts.

Financial history and recent banking and market events highlight the difficulty of controlling experts, notably because of their creativity (Meric \& Sfez, 2011). In 1958, the American interest-rate cap, combined with fears of a freeze of Soviet assets held in dollars, led to the creation of a Eurocurrency market on which foreign deposits in domestic currency were not subject to state control. More recently, the 2009 AMF (Autorité des Marchés Financiers Financial Markets Regulator) regulations prohibiting short sales of certain securities proved to be ineffective when traders worked around them by trading on markets exempt from these regulations. Regulatory measures, even increasingly rigorously enforced measures, are ineffective because of the leeway they allow experts. For instance, the freedom afforded to banks to assess their market assets using prudential ratio calculations (historical cost or value at risk) also allows them to control the flow of credit (Lamarque \& Maurer, 2009). Paradoxically, regulations can even stimulate expert creativity. International capital market control mechanisms have always been dodged by financial innovation (Sfez, 2010).

\section{Practice as a Prerequisite for Understanding Expert Activity}

Over 20 years of practice turn has created numerous possibilities in comprehensive research into companies. Reducing, or, conversely, expanding the spectrum of considerations to include different practices, practice, and practitioners (Whittington, 2006) allows researchers to question or even overcome dichotomies previously inextricable from management theory. It would also seem that paradoxes opposing theory and practice, management and labour, and strategy and tactics structure to day-to-day operations are often paralyzing (Mintzberg, 1983). 
The syncretism of the subject under study (Bazin, 2011) and the recursive relationship of practice with social structures (Giddens, 1984) are likely the main markers of such research. Our understanding of practice is based on the definition of praxis put forth by Castoriadis (1988): doing and the awareness thereof simultaneously, and externally directed. The task is then to study emerging localized and contextualized phenomena, at the level of de Certeau's "whispers of the everyday" (“murmures du quotidien"; 1980), rather than explicit, deliberate processes.

Why is an approach based on a clarification of practice particularly well suited to the control issues surrounding expert activities? First, so-called classic control mechanisms presume a passive, or, at worst, furtive player (see the Rainbarrel case, S. Kerr, 2003). Control is exerted and, if the net is sufficiently fine, risk is minimized. In the case of expertise (Meric \& Sfez, 2011), the extent of experts' knowledge of processes, products, methods, techniques, and sciences places them beyond the reach of conventional control mechanisms if they so choose. Along with the informational asymmetry proposed in the theory of the firm (Jensen \& Meckling, 1976), there is an asymmetry of knowledge and skills between the controller and the controlled. In other words, a considerable portion of experts' activities takes place beyond the purview of the controller not because these activities are hidden, but because they are imperceptible.

For controllers, and in this research approach, relying on a study of expert activity (through procedural or cartographic patterns, for instance) would merely reinforce these blind spots. Activity models cover narrow, static spectra, while expertise is diverse, dynamic, and emerging.

For these reasons, expert-control mechanisms only operate from reflexive control (Giddens, 1984) wielded by the experts themselves. Only experts are able to provide a tangible, 
intelligible overview of their practices and of the evolution of these practices according to specific constraints and opportunities.

This approach requires a method able to capture the reflexive nature of experts' own perspective on their activities, which will be discussed.

\section{Trading: An Expert Activity}

Experts practice activities that are hard to control, and trading is no exception. In our research, we have defined a trader as a market operator who manages financial assets on behalf of a bank or clientele (such as product sellers, designers, or structurers) (Jacquillat \& Levy-Garboua, 2013). In trading rooms, social divisions into front, middle, and back office privilege the transactional (Godechot, 2005), and it falls to those who are closest to the market - the tradersto carry out the transactions. Transactions are rooted in a social structure that shapes uncertainty into risk (Preda, 2005). Traders hold a central position in that transformation, and thus can be qualified as experts given the nature of their skills, according to the Castel (1987) criteria for expert representation. According to Castel, there are two models (not mutually exclusive) to represent expert intervention. The classic representation is of an individual mandated to assess a given situation based on his or her knowledge. The alternate model is that of an "instituting" expert, who creates situations through his or her knowledge. Traders may be considered experts in light of both models. The specialization of this professional category by market and by product category places experts first and foremost in a market-assessment situation. This evaluation then leads experts to construct new situations and practices that may lead to financial innovation. The legitimization process for each of these two models is different, and may be used to understand the challenges inherent in trying to control trading. In the mandated expert model, the technical activity of assessing information, based on hyperspecialization, may lead to obverse effects (for 
instance, underevaluating risk). The instituting expert model leads to professional practices that become implemented standards, the development of which excludes those outside the professional field. According to these two models, experts are characterized by specialized or even esoteric knowledge that leads to a particular division of labour, a phenomenon described in general terms by Reed (1996): knowledge workers are organized through networks, and adopt power strategies based on the "marketization" of their knowledge. Their skills development hinges on increasing specializations that are difficult to control through bureaucratic measures (Starbuck, 1992). It is therefore necessary to deploy network control mechanisms that can adapt to the flexibility and economy of knowledge experts. The Control Risk Resiliency (C2R) project exemplifies the challenges of controlling knowledge experts.

\section{Case Study: Operational Risk Control in Bank Trading}

Our case study highlights the conflict between the methodology used to establish checkpoints in a mechanistic understanding of banking activities and certain categories of expertise, in particular in the field of trading. Following the research carried out as part of the ANC-C2R and its somewhat disappointing results, a second phase of research has analyzed the reasons for that relative failure. After outlining the complementary $\mathrm{C} 2 \mathrm{R}$ research platform, we will present the aspect of the empirical results that highlighted its principal limitations - the controllability of bank trading.

General Research Context: The C2R Control Risk Resilience Project and

\section{Understanding Operational Risk}

With support from the Pôle de Compétitivité Mondial Finance-Innovation, the Ile-deFrance region and the Ville de Paris, C2R has since 2010 gathered a consortium including two private companies (a software editor and a consultancy firm) and two academic teams from 
French universities. With a budget of approximately $€ 2$ million, this project seeks to develop an operational risk management diagnostic tool for global use by banks. As the Basel Committee indicated, these risks are linked to potential losses due to the inadequacy or failure of internal procedures, to staffing, or to systems, as well as losses due to external events. Operational risk includes data entry errors, handling errors during stock exchange orders, loan defaults due to insufficient client file analysis, as well as massive claims tied to fraud such as the Kerviel case. The stakes are potentially enormous, because providing proof of adequate risk management in such cases raises the possibility of authorizing a bank, under the Basel I and Basel II workgroup regulations, to lower its prudential capital adequacy ratio by several tenths of a point.

The project hopes to identify approximately 500 key banking control-management checkpoints in order to provide a reference framework for external or internal auditors that is as exhaustive as possible. Very early on, the bulk of project resources were devoted to mapping these checkpoints, ${ }^{\text {ii }}$ based on models of typical banking processes through individual examination of the different business lines defined by the Basel Committee (business financing, retail banks, asset management, etc.).

It was almost immediately apparent that the mapping process served to identify objective and recurrent risk, but not constructed and evolving risk (technical committee meeting minutes, May 7, 2010). From that point on, the professional teams, along with some of their academic colleagues, turned their attention to mapping the processes linked to the most stable and routine business lines: retail banking and business financing. The rest of the project team (including researcher 1) focused on studying risk emergence dynamics in trading as one component of asset management and market activities: trading.

\section{Methods}


Trading activities were considered from an action-based research approach. The objective of the $\mathrm{C} 2 \mathrm{R}$ steering committee was to produce control instrumentation interactively with the field itself. The nature of the instrument has not a priori been defined, but it has been requested that the tool developed make the sources of operational risk "visible and intelligible" (Liu, 1997). Researcher 1 , a member of the $\mathrm{C} 2 \mathrm{R}$ team, has gathered primary data (direct observation) and secondary data (technical and steering committee records and notes) during the risk mapping implementation phase. Appendix 1 provides an inventory of sources. A reflexive triangulation mechanism was implemented with researchers 2 and 3, who, by assisting researcher 1 in identifying nonroutine elements in the study data, engaged in an iterative interpretation validation process (Girin, 1989).

While the practical component opens the door to a variety of research methods (see part IV, Golsorkhi, Rouleau, Seidl, \& Vaara, 2015), the approach selected to study a practice remains ethnographic in order to privilege direct observation of what is in the process of being carried out. Nevertheless, in the case of this study in particular, such an approach seemed potentially sterile. As has been mentioned, researchers, like controllers, cannot claim to discern the expertise of their trader subjects through mere physical alteration. Not only is the information held by each party asymmetrical, but the knowledge gap also makes it impossible for researchers to perceive what they have come to study (Devereux, 1967). Given the considerable degree of operational complexity and instability, participatory observation is impossible: researchers would have to become high-level traders themselves, which is time-consuming, and accessible neither to researchers nor even to middle-office staff. Similarly, nonparticipant observation would not yield results either. At best, the phenomena observed would be impossible to interpret without having attained the subjects' degree of expertise, and at worst the psychological dexterity of the experts 
would obscure any significant observable detail. Unconstrained insider testimony therefore seemed to be the most appropriate approach.

Balogun, Huff, and Johnson (2003) deemed self-reporting as an ethnographically complementary method, and self-reporting has since been recognized as sufficient to generate information on practices, notably in complex environments in which immersion would provide extremely limited perceptions of the phenomena under study. In their contribution to the methodology section of Strategy as Practice, Balogun, Beech, Johnson (2015) and Rouleau (2015) pointed out that narration is both a practice in and of itself, and a means of accessing the praxis and theories anchored in daily strategic practice. Strategically speaking, narrative reconstructions reveal agency and responsibility assignations. Even if it remains a rationalization, narration nonetheless allows a reflection on past actions (Giddens, 1984; Whittington, 2010) and therefore provides an explanation of the causal relationships that underpin the actions of each individual (Zuber-Skerritt, 2010).

Data were gathered through interviews with four experienced professionals with whom researcher 1 is personally acquainted and who, outside their work hours, agreed to provide a behind-the-scenes perspective on the work of traders, desk officers, asset managers, and branch directors whose work relates to trading. The interviews took place in financial centres in London and Paris and lasted a total of 12 hours. In order to encourage interviewees to speak freely, we are committed to maintaining the anonymity of all interview subjects and of the banks involved. ${ }^{\text {iii }}$

The informal nature of the interviews was an integral part of our research methodology in order to not only access a deeper wealth of information, but especially to minimize distortions between spontaneous and elicited narration (Wolfson, 1976). This approach allows interviewees to reflect on their activities beyond the institutional constraints of both their companies and of the research apparatus. 
Each individual was interviewed twice consecutively, for validation and to follow up on issues raised in the first interviews; the two interviews also helped develop trust between the researchers and subjects. In a number of instances, nonroutine facts emerged during the second interview.

In order to eliminate any possible cultural bias in the analysis of disciplinary systems, banks from different nationalities (American, French, Swiss, British) were selected. The results obtained were then compared with secondary field data produced by other scientists in the Paris trading world (Godechot, 2005; Godechot, 2007; Lenglet, 2009). These authors notably point out the disparity between traders and middle-office staff, as well as the increasing Balkanization of trading due to the diversification of financial instruments. This gap is not only technical, but also psychological and social. It is not unheard of for desk officers to refer to their middle-office colleagues using derogatory slang for police officers (“bœuf-carotte”; Lenglet, 2009).

\section{Particularities of Trading with Regards to Operational Risk: Empirical Results iv}

Two categories of results fall under the broader auspices of expert creativity: those results touching on organized and cleared market trading (typically shares, bonds, and nonexotic derivatives), and those related to over-the-counter markets, which tend to be more complex and less transparent, and in which expert creativity has reached even greater levels.

The organized-market interviewees mentioned not only the inadequacy but indeed the harmfulness of a rigid checkpoint structure to attempt to exert some small measure of control over operational risk. A consensus emerged in the interviews on the following major points, some of which apply also to over-the-counter trading (items and transcriptions in Appendix 2): 
1. An excess of control nullifies control for both organized-market trading and for over-thecounter activity.

2. Diversity in control mechanisms is more efficient than the creation of endless control mechanisms.

3. A mobile control unit is more efficient in terms of intervention methods and procedures than a static bureaucracy.

4. Controllers must remain unpredictable for traders.

5. The expertise gap between traders and controllers renders control mechanisms ineffectual.

6. The first level of control is subject to social inhibition when compared to the status of traders.

7. Upper-level control mechanisms are not independent.

A number of risks are specific to over-the-counter trading due to its extreme complexity (items and transcriptions in appendix 3):

8. Too many transactions completed to quickly inevitably give rise to breaches in the control mechanism.

9. Some over-the-counter transactions are too complex to be entered into bank records.

10. Over-the-counter-related risks are not able to be anticipated and therefore not calculable, which undermines banks' overall value-at-risk calculations.

The experts interviewed confidentially and anonymously were candid about their doubts regarding the efficiency of bureaucratic control mechanisms on their own activities. Their ability to analyze loopholes in control mechanisms and to design more efficient alternate mechanisms demonstrates the extent to which the ability to fly under the radar of controllers, at every level, from the middle office to the Inspectorate General (Inspection générale des finances - IGF) is 
taken into consideration in the reflexive control trading experts exert on their own actions. At no time did the traders or desk officers interviewed attempt to suggest that the examples they raised were anecdotal, isolated, marginal, or nonduplicable. On the contrary, these examples (such as actual risk concealment by the middle office, or the difficulty of booking trades) are part of what traders consider integral to recurrent and reflexive practices. The field of action reveals a praxis that has not become so routine that it is immutable or unconscious: these actions are conscious in the moment at which the trader avoids or subverts regulatory devices, and are sufficiently new to be undetectable by control systems. The gap between routine and innovation, fluid and intangible to outsiders, but familiar to experts, can be divided into three general groups:

- An excess of information and complexity, leading to limited rationality affecting control (points 1, 2, 6, 9, and 11).

- The limits of automation, which cannot replace this limited rationality (points 3 and 10).

- The need for a strategic and tactical attitude, irreducible to procedural implementation (points 3, 4, 5, and 7).

Access to the reflections of experts speaking confidentially outside of their institutional context highlighted the intrinsic double limitation of trading controls. On one hand, controlling traders is inefficient as soon as it is taken on by external professionals, due to traders' creativity, which in itself helps legitimize their participation in their peer network (that is, other market professionals). On the other hand, the intrinsic agility of traders, as highlighted here, nullifies any of the usual bureaucratic tools for use by ill-intentioned individuals. The quality-assurance risk management systems with predetermined checkpoints typical of classic retail banking business lines truly leave a company defenseless. Finally, expert-control dynamic are permanently 
disjointed from the evolving practices implemented according to expert creativity. Overcoming this double limitation is the central objective of any expert-control attempt.

\section{Discussion: Trading Expertise-A Manageable Operational Risk?}

These research results confirm first and foremost the hypothesis according to which an expert activity such as trading is likely to engender immeasurable operational risks (Meric \& Sfez, 2011). Meric and Sfez, like Lamarque and Maurer (2009) before them, suggest that, beyond flat metrics and mapping, controlling these risks is a management problem. If we grant that the object of such research could be to produce engineering-level knowledge (Martinet \& Pesqueux, 2013), the reflexive expression of trading practices could provide the basis for the development of new control mechanisms. A preliminary interpretation of these results lies in the recommendations of the experts themselves. Their diagnosis is aligned with the solutions proposed for cybercrime by Guarnieri and Przyswa (2012): to the shadowy nature of the internet and the elusive behaviours to which it gives rise, "collection agencies" of a sort must be created to turn a likelihood into a risk (Beck, 2008). Secondly, therefore, new control mechanisms must be multidimensional, integrated, and dynamic.

\section{How to Control the Experts: Turning Expertise against Itself}

The nature of operational risk management (Lamarque \& Maurer, 2009) suggests that a solution may be found in informal control - that is, in power relationships as opposed to authority (Bouquin, 2011). In their literature review on fraud, Le Maux, Smaïli, and Ben Amar (2013) also suggested that positive-accounting hypotheses did not provide adequate solutions, notably because traders currently enjoy a considerable margin of authority under their superiors. When 
questioned, by their own initiative, they suggested reversing this relationship by beating them at their own game.

Research has revealed that the difficulty of controlling experts arises from their creativity, the lack of transparency in their activities, and their professional dexterity. In response to the foregoing, an interactive and diagnostic control mechanism (Simons, 1994) should be equally lacking in transparency (not in its results, but in its operational application), constantly creative,

fluid, and unpredictable. Control mechanisms should give rise to practices that are constantly reinvented, rather than systematically mirroring local innovations through regulations and routines that are obsolete as soon as they're implemented (Sfez, 2010).

Such practices, which it is not our place to define because they must be developed in a particular context by competent stakeholders in fields of expertise that are extremely specific, require a rethinking of the administration and governance of banking controls. As Guarnieri and Przyswa (2012) suggested that for high-level cybercrime, pools of experts including high-level traders should be gathered to recommend control mechanisms to those able to wield them. Due to fixed and especially to variable bonuses, it is hard to imagine that traders could step into the role of controllers. Expertise in the field of trading furthermore quickly becomes obsolete. An oversight and advisory board may be preferable. Traders themselves furthermore suggest that desk hierarchies give rise to asymmetrical risks between controllers and the positions they control. Banking control governance should strive to re-establish some symmetry, and ensure that controllers' careers are not threatened if they denounce reprehensible or potentially harmful practices..

How to Control the Traders? The Need for Integrated, Dynamic, Multidimensional Control Mechanisms 
Can the complexity inherent in expert control be satisfactorily addressed through control mechanisms, tools, or structures? Traditional control mechanisms tend to be discounted because they are one-dimensional, and due to the weakness of their foundational model (Hofstede, 1981), which does not reflect or at best oversimplifies complex situations. Projects like C2R devote most of their budgets to such approaches based on checkpoint-based methods such as COSO framework-inspired scales and audit and internal verification best practices. A performance assessment process based on expert knowledge could be considered, or a mechanism to reduce the blocking ability of a given category of experts, but it is difficult to conceive of a series of operations able to address both problems simultaneously.

Modal or leverage approaches to control refer back to the rational foundations of control (Weber, 1971) and to the modality of action (the question of how, Chiapello, 1996; Simons, 1984). Modes furthermore indicate a system of focal points used to analyze a specific practice, while leverage is activated sequentially. Their interactions, by contrast, either fade into the background or are absent from the proposed theoretical frameworks. In this regard, these approaches are more global than integrative — that is, they provide an overall perspective.

Would an integrative approach (for instance, a systemic approach; Anthony, 1965) to control be sufficient to mitigate the difficulty of controlling experts? Perhaps not, since systemic approaches base their actions on multitemporal and transorganizational scales. Expert creativity has an impact both within and beyond the organization, as the examples above illustrate (professional legitimacy versus company loyalty). They are furthermore based on distinct timelines or time structures (Orlikowski \& Yates, 2002), which control systems must take into account. For instance, a trader might design an extremely short-term arbitrage gain operation, in keeping with a long-term portfolio management strategy. Alternatively, and more prosaically, 
speculation reveals anticipatory situations in which time and amplitude belong only to the market experts involved.

Beyond procedural or systemic approaches, these constraints call for an understanding of control dynamics within and outside of companies. A dynamic approach refers first and foremost to the evolving, transitory nature of the situations that must be controlled. In this regard, Hatchuel and Weill (1992) pointed out that it would be fallacious to include expert behaviour in the stability of a strategic framework, and preferred instead to see control-related schemes as "the transitory effects of a regulatory system operating within the permanent interaction of knowledge" (Hatchuel \& Weill, p. 106). These dynamics also point to the interactions that govern the organization, and its relationship to the environment (Liu, 2007; Morin, 1991). The diagnostic and analytical frameworks derived must meet at least three requirements. First, they must not over-personalize control dynamics, lest they miss the systemic effects produced independently of stakeholders' intentions. Secondly, they must not be limited to a single timeline, since experts' ability to manipulate the short, intermediate and long term would fall beyond the scope of the analyses. Finally, they must not be limited to a fixed organizational perimeter, lest the role of more or less formal expert networks, for instance, not be taken into consideration. To meet these requirements, a representation combining various temporal and spatial issues must be considered.

\section{Conclusion: Explaining Expert Practices in order to Control Them}

Considering traders to be representative of a particular class of experts, it is necessary to approach the control of their activities through their own reflexive narrative of their practices. When Beck (2008) suggested that a diffuse threat be transformed into a tangible risk through a "collection agency," he is referring to the hold of science over society. This current research 
suggests that various trading expertise is not subject to simple modelling, and requires knowledge arising from extremely specific experience. By explaining the multiple dimensions and timelines according to which traders conceive of their practice, it would seem that only traders are able to provide avenues for designing the mechanisms to control their own activities; they even outline the causalities that shape their day-to-day professional lives, reaching a consensus on the representation of an opaque, fluid, random, and creative control, similar to their own practice. Trading experts' conception of their own profession also highlights the necessity of basing such a control mechanism on a multidimensional framework. The logic of these requirements, as well as the multiple timelines from which they arise, must be explained before particular control mechanisms can be developed. Such an approach has the advantage of not reducing the complexity of the control dynamics in financial institutions. It allows not only the understanding of the distinct logic according to which controllers and the controlled operate, but also offers the possibility of understanding how these seemingly distinct logical systems interact to give rise to new forms of operational or financial risk.

A future avenue for research would be the design, based on the same data, of a method able to represent these multiple dimensions and timelines in order to restore the complexity of causalities at work in expert practices. 


\section{JEL Classification:}

\section{References}

Abernethy, M.A., \& Stoelwinder, J.U. (1995). The role of professional control in the management of complex organizations. Accounting, Organizations and Society, 20(1), 117.

Anthony, R.N., (1965). Planning and Control Systems, a framework for analysis. Boston: Harvard University Press.

Balogun, J., Huff, A. S., \& Johnson, P. (2003). Three responses to the methodological challenges of studying strategizing. Journal of Management Studies, 40: 197-224.

Balogun, J., Beech N., \& Johnson P. (2015). Researching strategists and their identity in practice: building close-with relationships. In Golsorkhi D., Rouleau L, Seidl D., Vaara E. (Eds), Cambridge Handbook of Strategy as Practice, pp. XXX-XXX. Cambridge: Cambridge University Press.

Bazin Y. (2011). L'institutionnalisation des pratiques organisationnelles. Le cas du diagnostic en psychiatrie, PhD Dissertation, 497p. Paris : CNAM.

Beck, U. (2008). La Société du risque. Sur la voie d'une autre modernité. Paris: Flammarion.

Bedard, J., (1989). Expertise in auditing: myth or reality? Accounting Organizations and Society, 14, (1/2): 113-131.

Bouchez, J.P. (2006). Manager des travailleurs professionnels du savoir : enjeux et perspectives, Revue Française de Gestion, 9-10 (168-169): 35-53.

Bouquin H. (2011). Les fondements du contrôle de gestion. Paris : PUF Que sais-je ?

Buton, F. (2006), De l'expertise scientifique à l'intelligence épidémiologique : l'activité de veille sanitaire, Genèses, 65 : 71-91. 
Castel, R. (1987). L'expert mandaté et l'expert instituant. Actes de la Table Ronde organisée par le CRESAL, Saint Etienne.

Castoriadis, C. (1998). La montée de l'insignifiance, Carrefours du labyrinthe Tome 4. Paris : Seuil.

Certeau (de) M. (1980). L’invention du quotidien. 1. Arts de faire. Paris: Gallimard.

Charrier, E. (2014), L'expertise judiciaire en économie-finance : vers une organisation collective de l'objectivité de l'expert, Histoire de la justice 24 : 251-259.

Chi, M.T.H. (2006). Two approaches to the study of experts'characteristics. In The Cambridge handbook of expertise and expert performance (Eds, Ericson K.A., Charness, N., Feltovich, P., Hoffman, R.). Boston: Cambridge University Press, 21-30.

Chi, M. T. H., Glaser, R., \& Farr, M. J. (1988). The nature of expertise. Hillsdale: Erlbaum.

Chiapello, E., (1996). Les typologies des modes de contrôle et leurs facteurs de contingence : un essai d'organisation de la littérature. Comptabilité - Contrôle - Audit, 2 (2): 51-74.

De Smet, A. A., Fryback, D. G., \& Thombury, J. R. (1978). A second look at the utility of radiographic skull examination for trauma. American Journal of Radiology 132: 95-99.

Devereux, G. (1967). From anxiety to method in the behavorial Sciences. The Hague: Mouton \& Co.

Einhorn, H. (1974). Expert judgment: Some necessary conditions and an example. Journal of Applied Psychology 59: 562-57 1.

Evetss, J., Mieg, H.A., \& Felt, U. (2006). Professionalism, scientific expertise an elitism. In The Cambridge handbook of expertise and expert performance, 105-123.

Fablet, A., \& Lacaze, D. (2014). Le rayonnement des Experts : vers de nouvelles pratiques de gestion des ressources humaines ? Gestion 2000 31: 49-67. 
Farrington-Darby,T., \& Wilson, J.R. (2006). The nature of expertise: A review. Applied Ergonomics 37: 17-32.

Guarnieri F., \& Przyswa E. (2012). Cybercriminalité et contrefaçon : pour une nouvelle analyse des risques et des frontières. Hermès. 63 (Murs et Frontières) : 175-180.

Giddens, A. (1984). The Constitution of Society, Outline of the Theory of Structuration. Cambridge : Polity Press.

Girin, J. (1989). L’opportunisme méthodique dans les recherches sur la gestion des organisations. Communication à la journée d'étude « la recherche-action en action et en question », AFCET, Collège de systémique, École Centrale de Paris (www.crgpolytechnique.fr/incunables/opportunisme.html)

Godechot, O. (2005) [2001]. Les traders. Paris: La Découverte.

Godechot, O. (2007). Working Rich : Salaires, bonus et appropriation du profit dans l'industrie financière. Paris: La Découverte.

Golsorkhi D., Rouleau L, Seidl D., \& Vaara E. eds (2015). Cambridge Handbook of Strategy as Practice. Cambridge: Cambridge University Press.

Hatchuel, A., \& Weill, B. (1992). L'expert et le système suivi de quatre histoires de systèmes experts. Paris: Economica.

Hofstede, G. (1981). Management Control of public and not-for-profit activities. Accounting, Organizations and Society 6 (3): 193-211.

Jacquillat, B., \& Levy-Garboua, V. (2013). Les 100 mots de la crise financière. Paris: Que sais je? PUF.

Jensen M., \& Meckling W.H. (1976). Theory of the Firm: Managerial Behavior, Agency Costs, and Ownership Structure. Journal of Financial Economics. 3 (4) : 305-360.

Kerr S. (2003). The Best Laid Incentive Plans. Harvard Business Review. January issue. 
Kunitz, S. (1974). Professionalism and Social Control in the Progressive Era: The Case of the Flexner Report. Social Problems 22 (1): 16-27

Lamarque, E., \& Maurer, F. (2009). Le risque opérationnel bancaire - Dispositif d'évaluation et système de pilotage. Revue Française de Gestion 191: 93-108.

Lelebina, O., \& Sardas, J.C. (2011). L'expertise et les experts dans les organisations. Une approche multidisciplinaire pour la définition des notions clés. Actes du XXIIe Congrès de l'AGRH, Marrakech, Maroc.

Le Maux, J., Smaïli N., \& Ben Amar W. (2013). De la fraude en gestion à la gestion de la fraude. Une revue de la littérature. Revue Française de Gestion, 231 : 73-85.

Lenglet, M. (2009). Aux marges de la triche ? Innovation normative et déontologie financière en salle de marché. Management \& Avenir 22: 263-284.

Liu, M. (1997). Fondements et pratiques de la recherche action. Paris: L'Harmattan.

Liu, M. (2007). Dynamique des Organisations. In La Gouvernance dans les Systèmes. Monza: Polimetrica Publisher, 151-154.

Martinet A.C., \& Pesqueux Y. (2013). Epistémologie des Sciences de Gestion. Paris : Vuibert.

Meric, J., \& Sfez, F. (2011). La créativité d'experts comme risque opérationnel : contournements et détournements de la régulation bancaire. Management \& Avenir 48: 32-50.

Mintzberg, H. (1993). The Rise and Fall of Strategic Planning. New York :The Free Press.

Montagna, P.-D. (1968). Professionalization and Bureaucratization in Large Professional Organizations. The American Journal of Sociology 74 (2): 138-145.

Morin, E. (1991). La méthode, t4 : les idées. 2nde édition, Paris: Le Seuil.

Orlikowski, W.J., \& Yates, J. (2002). It's about time: Temporal Structuring in Organizations. Organization Science 13 (6): 684-700. 
Orlikowski, W. J. (1991). Integrated Information Environment or Matrix of Control? The Contradictory Implications of Information Technology. Accounting, Management and Information Technologies 1(1): 9-42.

Preda, A. (2005). Legitimacy and status groups in financial markets. The British Journal of Sociology 56 (3): 451-471.

Reed, M. I. (1996). Expert Power and Control in Late Modernity: An Empirical Review and Theoretical Synthesis. Organization Studies 17(4): 573-597.

Rouleau L. (2015). Studying strategizing through biographical methods: narratives of practices and life trajectories of practitioners. Cambridge Handbook of Strategy as Practice, Golsorkhi D., Rouleau L, Seidl D., \& Vaara E. (eds), Cambridge: Cambridge University Press.

Selinger E., \& Crease R. P. (dir.) 2006.The philosophy of expertise, New York, Columbia University Press,.

Sfez, F. (2010). L'évolution du marché des euro-obligations de 1963 à 2008 : une organisation au risque de la bureaucratie, Thèse de doctorat en Sciences de Gestion, Paris : CNAM.

Shanteau, J. (1992). Competence in Experts: the Role of Tasks Characteristics. Organizational Behavior and Human Decision Processes 53: 252-266.

Shanteau, J. (1988). Psychological characteristics and strategies of expert decision makers. Acta Psychologica 68: 203-215.

Siegler, R. (2013), Commentary: How do people become experts? In Expertise and skill acquisition: the impact of William G. Chase, (Ed. Staszewski, J.)

Simons, R. (1994). How New Top Managers Use Control Systems as Levers of Strategic Renewal. Strategic Management Journal 15 (3): 169-189. 
Starbuck, J. (1992). Learning by knowledge-intensive firms. Journal of Management Studies, 29 (6): 713-740.

Trépos, J.Y. (1996). La sociologie de l'expertise. Paris: Que sais je?

Thévenet, M. (2006). Tous professionnels. Revue Française des Sciences de Gestion 9 (168-169): $15-34$.

Weber, M. (1971). Economie et Société, ed. originale 1922, Tome 1, Paris: Plon.

Whittington, R. (2006). Completing the Practice Turn in Strategy Research, Organization Studies, 27 (5): 613-634.

Whittington, R. (2010). Giddens, structuration theory and strategy as practice. Cambridge Handbook of Strategy as Practice, Golsorkhi D., Rouleau L, Seidl D., Vaara E. (eds), Cambridge: Cambridge University Press.

Wolfson, N. (1976). Speech Events and Natural Speech: Some Implications for Sociolinguistic Methodology. Language in Society 5(2): 189-209.

Zuber-Skerritt O. (2001). Action Learning and Action Research: Paradigm, Praxis and Programs. Sankara, S., Dick, B. and Passfield, R. (eds). Effective Change Management through Action Research and Action Learning: Concepts, Perspectives, Processes and Applications, Lismore: Southern Cross University Press. 1-20. 


\section{Appendix 1: List of Main C2R Study Research Components}

- 000 - Excerpt, Pôle de Compétitivité Finance-Innovation application

- $\quad 001-20100326$ - Reference document

- $002-20100326$ - Guidelines

- $\quad 003-20100326-$ COPIL - Minutes

- $004-$ C2R_Retail bank V5 (Process and checkpoints mapping)

- $\quad 005$ - C2R-0063-DR-20101217 - COPIL - Minutes V1.0

- 006 - C2R-0063-DR-20110527 - COPIL - Minutes V1.0

- 007 - C2R-0063-DR-20110622 - COPIL - Minutes V1.0

- $\quad 008$ - C2R-0063-DR-20110722 - COPIL - Minutes V1.0

- $\quad 009-\mathrm{C} 2 \mathrm{R}-0063-20111220-\mathrm{COPIL}-$ Minutes

- $\quad 010-\mathrm{C} 2 \mathrm{R}-$ Project summary 31_12_2011 V1

- 10BIS - C2R-0064-DR-20120216 - COPIL - Minutes V1.0_MDP

- $\quad 011$ - C2R-0063-DR-20120329 - COPIL - Minutes V1.0

- $\quad 011$ - C2R-0063-DR-20120612 - COPIL - Minutes V1.0

- 012 - C2R-0093-DR-20121029 - COPIL - Minutes V1.0

- $013-$ Budget

- 014 - C2R-0124-DR-CR-C2R_Cotec_20110408.V1

- 015 - C2R-0124-DR-CR-C2R_Cotec_20101112.V1

- $016-$ C2R_Banque de détail V9 (Retail bank)

- $\quad$ 016BIS - C2R-0109-DR-CR-C2R_Cotec_20100701

- 017 - C2R_Banque de détail_Crédit entreprises V15 VVSP (Retail bank business credit)

- $\quad 018-$ C2R_Financement_Entreprises V4 VJEP (Business financing)

- $019-$ C2R_Gestion_d'actifsv2 (Asset management) 
- M001 - Copil, 26 March, 2010 - Handwritten notes

- $\quad$ M002 - Cotec, 7 May, 2010 - Handwritten notes

- $\quad$ M003 -Copil, 1 July, 2010 - Handwritten notes

- M004 - Cotec, 31 August, 2010 - Handwritten notes

- $\quad$ M005 - Cotec, 28 September, 2010 - Handwritten notes

- M006 - Copil, 17 December, 2010 - Handwritten notes 


\section{Appendix 2: Empirical Results: Trading Experts' Reflexive Considerations of Risk Control}

(*Characteristics Specific to OTC Trading are Marked with an Asterisk)

\begin{tabular}{|c|c|c|}
\hline Researcher synthesis & Expert self-assessment & Comments \\
\hline $\begin{array}{l}\text { An excess of control } \\
\text { undermines the } \\
\text { effectiveness of that } \\
\text { control. }\end{array}$ & $\begin{array}{l}\text { Current procedural } \\
\text { mechanisms are inadequate } \\
\text { because they rob managers of } \\
\text { the synthetic, } \\
\text { multidimensional vision } \\
\text { required to detect major risk. } \\
* \text { Automatically generated } \\
\text { operational-issue detection } \\
\text { checklists are inadequate. }\end{array}$ & $\begin{array}{l}\text { "For } 10 \text { years, we have seen an increase in } \\
\text { successive regulations, which in the end killed } \\
\text { the very possibility of control. There is even a } \\
\text { procedure that dictates how frequently } \\
\text { controllers must be controlled! There is no } \\
\text { synthesis, we are drowning in procedural detail, } \\
\text { and we are blind to basic risks." } \\
\text { * "There was a list of all the problems, but it was } \\
\text { so long that we [desk officers] signed everything } \\
\text { without even looking." }\end{array}$ \\
\hline $\begin{array}{l}\text { Diversity is more } \\
\text { efficient } \\
\text { quantity. }\end{array}$ & $\begin{array}{l}\text { Fewer but multipronged } \\
\text { oversight mechanisms are } \\
\text { required to monitor trader } \\
\text { activity. } \\
\text { * Filter and serialize } \\
\text { information according to five } \\
\text { key questions; know how to } \\
\text { spot possible fraud linked, for } \\
\text { instance, to loss concealment } \\
\text { through false transactions } \\
\text { rebooked daily to balance } \\
\text { P\&L but lost in exhaustive } \\
\text { daily transaction listings. }\end{array}$ & $\begin{array}{l}\text { "If there are several cameras filming a soccer } \\
\text { match, they'll manage to find a fault that a single } \\
\text { referee couldn't have seen, because another } \\
\text { player was in the way. But if there are } 500 \\
\text { cameras, they can't see anything at all, like the } \\
\text { intelligence agents that didn't see } 9 / 11 \text { coming } \\
\text { because they were drowning in information." } \\
\text { * “1) Unbooked trades (from oldest to most } \\
\text { recent, nothing abnormal up to about } 10 \text { days } \\
\text { delay); 2) Approximation; 3) Unconfirmed } \\
\text { trades; 4) The number of trades modified or } \\
\text { cancelled by traders; and 5) Details of all trades } \\
\text { with P\&Ls in excess of £250,000.” }\end{array}$ \\
\hline
\end{tabular}




\begin{tabular}{|c|c|c|}
\hline $\begin{array}{l}\text { Fluid, mobile } \\
\text { oversight is better } \\
\text { than static, } \\
\text { bureaucratic control. }\end{array}$ & $\begin{array}{l}\text { The Kerviel affair shows that } \\
\text { a new paradigm of control } \\
\text { mechanism is required. }\end{array}$ & $\begin{array}{l}\text { "The Kerviel affair could have been detected in } \\
\text { two weeks if that bank had had an internal unit } \\
\text { made up of } 10 \text { highly qualified, high-level, hyper- } \\
\text { mobile individuals with basic surveillance } \\
\text { procedures." }\end{array}$ \\
\hline $\begin{array}{l}\text { Control agents must } \\
\text { be unpredictable. }\end{array}$ & $\begin{array}{l}\text { Traders' professional } \\
\text { dexterity requires randomized } \\
\text { controls. }\end{array}$ & $\begin{array}{l}\text { "It would be extremely dangerous if the } \\
\text { checkpoints were known in advance [...] The less } \\
\text { a trader knows about control procedures, the } \\
\text { more those procedures are effective. Control } \\
\text { mechanisms must therefore be changed fairly } \\
\text { often. It's like the entrance passcode to a } \\
\text { building: after a while, everyone knows it [...] To } \\
\text { truly manage risk, you have to recruit former } \\
\text { traders with the same level of expertise as those } \\
\text { they are controlling. With Kerviel, we did the } \\
\text { opposite, we appointed someone from the middle } \\
\text { office." }\end{array}$ \\
\hline $\begin{array}{l}\text { Expertise gaps } \\
\text { leaves controllers at } \\
\text { a disadvantage. }\end{array}$ & $\begin{array}{l}\text { Controllers must have } \\
\text { sufficient expertise to vary the } \\
\text { nature and the frequency of } \\
\text { controls; traders can easily } \\
\text { ensure the middle-office } \\
\text { approvals of false portfolio } \\
\text { valuations. }\end{array}$ & $\begin{array}{l}\text { "Controllers must also be aware of what is going } \\
\text { on on the market. There are times when the } \\
\text { reaction time must be much quicker; if there is } \\
\text { some instability, it has to be resolved by the end } \\
\text { of the day, otherwise a portfolio could drop by } \\
20 \% \text { [...] Controllers too far down the ladder } \\
\text { will never be able to understand that the } \\
\text { correlation matrices are climbing and you stand } \\
\text { to lose a lot if you're short on Peugeot and long } \\
\text { on Renault." } \\
\text { "For example, a trader might tell the middle } \\
\text { office, 'these shares are worth 100', when the } \\
\text { market is in fact illiquid and shallow, and the }\end{array}$ \\
\hline
\end{tabular}




\begin{tabular}{|c|c|c|}
\hline & & $\begin{array}{l}\text { bond price is six month old, the date of the last } \\
\text { transaction, the trader knows that if he sells } \\
\text { tomorrow it will be at 80, and the middle office } \\
\text { doesn't know. And the trader says, "I know this } \\
\text { market, I've been here for } 10 \text { years, and I'm } \\
\text { telling you it's worth 100'. You need a controller } \\
\text { with enough expertise to understand that depth } \\
\text { takes it over volatility." }\end{array}$ \\
\hline $\begin{array}{l}\text { Major banks, } \\
\text { France: social } \\
\text { inhibition of middle- } \\
\text { office controller. }\end{array}$ & $\begin{array}{l}\text { Middle officers exert little } \\
\text { authority over traders. }\end{array}$ & $\begin{array}{l}\text { "There is an army of us who graduated from } \\
\text { prestigious schools, with their almost military } \\
\text { culture, where everyone wants to outdo everyone } \\
\text { else. The middle office, with fewer graduates, } \\
\text { must wait until traders have a free second to } \\
\text { speak to them. It's a little bit like the makeup } \\
\text { artist on a movie set who wants to talk to the } \\
\text { star." }\end{array}$ \\
\hline $\begin{array}{l}\text { Upper-level control } \\
\text { positions tend to be } \\
\text { springboards and } \\
\text { undermine the } \\
\text { independence of } \\
\text { controllers. }\end{array}$ & $\begin{array}{l}\text { Career management does not } \\
\text { reward inspectors or } \\
\text { controllers who are } \\
\text { whistleblowers. }\end{array}$ & $\begin{array}{l}\text { "The position of Inspector General is the best } \\
\text { way to become a director. We are discouraged } \\
\text { from questioning the most profitable activities, } \\
\text { and from rifling through the affairs of those who } \\
\text { are looked upon favourably by management." }\end{array}$ \\
\hline
\end{tabular}




\section{Appendix 3: Risk and Control Particularities of OTC Trading}

\begin{tabular}{|c|c|c|}
\hline $\begin{array}{l}* \text { Too many } \\
\text { transactions, too } \\
\text { fast: inevitable } \\
\text { control breakdown. }\end{array}$ & $\begin{array}{l}* \text { Trade volume } \\
\text { and pace } \\
\text { increase } \\
\text { operational risk. }\end{array}$ & $\begin{array}{l}\text { * "Every desk is in a daily race for trades." } \\
\text { * "The same thing applies to a high-debit broker." } \\
\text { * "In some businesses, the transaction frequency is so high } \\
\text { that the middle office would be unable to validate all } \\
\text { transactions." } \\
\text { * “A commodities-to-exchange rate trade would be booked } \\
\text { twice, and in two different systems. We need to create software } \\
\text { that reconciles both systems, but the costs are linear: if } \mathrm{n} \\
\text { systems must be reconciled, n(n-1)/2 reconciliations are } \\
\text { theoretically systematically needed at day's end." } \\
\text { * "The panacea that would be a single system for all asset } \\
\text { classes, but that would be the grail." }\end{array}$ \\
\hline $\begin{array}{l}\text { * Some OTC trades } \\
\text { cannot be entered } \\
\text { into banking } \\
\text { information systems. }\end{array}$ & $\begin{array}{l}\text { Complex } \\
\text { international } \\
\text { trades involving } \\
\text { several asset } \\
\text { classes are not } \\
\text { bookable. }\end{array}$ & $\begin{array}{l}\text { * "It is generally thought that the qualities of a trader include } \\
\text { knowing whether a trade is bookable or not. Banking } \\
\text { governance has no blocking clause on the matter." } \\
\text { * "The danger is a poor counterparty risk assessment due to } \\
\text { complex transactions." } \\
\text { * "Take variable convexity trading, for instance... That's } \\
\text { going to blow up in our faces someday." } \\
\text { * "Trades can sit around unsigned for six months. It's rare, } \\
\text { but it can slip under the radar." }\end{array}$ \\
\hline $\begin{array}{l}* \text { OTC risks are } \\
\text { noncalculable. }\end{array}$ & $\begin{array}{l}* \text { Value-at-risk } \\
\text { calculations are } \\
\text { not } \\
\text { representative. }\end{array}$ & $\begin{array}{l}\text { * "Covariances between different currencies are integrated } \\
\text { realistically (dollar-yen, dollar-pound, dollar-euro, etc.)..." } \\
\text { * "We don't know how to integrate every trade into a value-at- } \\
\text { risk system: complex trades aren't recorded in the same } \\
\text { information system as simple trades, and it would take too } \\
\text { much time to calculate." }\end{array}$ \\
\hline
\end{tabular}




\section{Notes}

i Experto cretite is a Latin expression meaning "Trust in those who have experience." It is derived from a quote in the Aeneid of Virgil (70 - 19 BCE).

ii The entirety of the project's official documents and deliverables, including technical committee (“Cotec") and steering committee (“Copil”) meeting minutes, as well as handwritten notes taken by one of the study authors during these meetings, notably showing any controversial or nonconsensual points in regards to which official documents are naturally less explicit once said controversies have been resolved. Procedural and checkpoint maps have also been kept, and are covered by a confidentiality clause.

iii Barring breaches of this anonymity, all handwritten interview and meeting notes are available to the scientific community. Interviewees agreed to reread their comments and to amend them if necessary, but did not agree to be recorded.

iv Partial results of this empirical study had previously been published in an academic journal (author), and in a professional journal (author). 